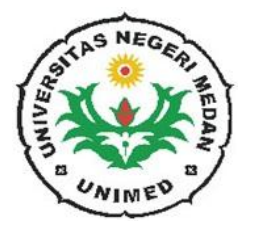

\author{
JURNAL BIOSAINS \\ (Journal of Biosciences) \\ http://jurnal.unimed.ac.id/2012/index.php/biosains \\ email : jbiosains@unimed.ac.id
}

\title{
TINJAUAN EKOLOGI FUNGI MIKORIZA ARBUSKULA
}

\author{
Ahmad Shafwan S. Pulungan \\ Jurusan Biologi, Universitas Negeri Medan \\ Email : pulungan@unimed.ac.id
}

\begin{abstract}
ABSTRAK
Fungi mikoriza arbuskula merupakan asosiasi antara fungi dengan akar tanaman. Asosiasi ini berkembang luas dialam, hampir sebagian besar tanaman mampu bersimbiosis dengan fungi mikoriza arbuskula. Kehadiran FMA pada akar tanaman dapat memberikan berbagai keuntungan kepada tanaman inang seperti perluasan daerah serapan hara, toleransi terhadap cekaman kekeringan, menghindarkan tanaman inang dari patogen tanah. Selain keuntungan tersebut, FMA dapat berkolaborasi dengan mikroorganisme tanah lainnya seperti dengan rhizobium. Secara umum, keduanya mempunyai kemampuan yang sama untuk membantu dan meningkatkan pertumbuhan tanaman inang. Hal lain yang menarik dari FMA adalah kemampuannya untuk ikut meningkatkan agregasi tanah. Kemampuan ini dapat digunakan untuk bidang pertanian dalam meningkatkan pertumbuhan dan hasil panen. Asosiasi antara tanaman dengan FMA, tanaman dapat lebih efisien dalam penyerapan unsur hara.
\end{abstract}

Kata kunci : simbiosis, pospat, patogen, pertumbuhan, miselia

REVIEW OF ECOLOGY FUNGI MIKORIZA ARBUSKULA

\begin{abstract}
Arbuscular mycorrhizal fungi is an association between fungi and plant roots. This association develops widely in the deep, almost most plants are able to symbiosis with arbuscular mycorrhizal fungi. The presence of FMA in plant roots can provide various benefits to host plants such as nutrient uptake areas, tolerance to drought stress, avoid host plants from soil pathogens. In addition to these advantages, FMA can collaborate with other soil microorganisms such as with rhizobium. In general, both have the same ability to help and improve the growth of host plants. Another interesting feature of the FMA is its ability to help increase soil aggregation. This capability can be used for agriculture in improving growth and yields. Association of plants with FMA, plants can be more efficient in the absorption of nutrients
\end{abstract}

\section{Key words : symbiosis, fosfat, pathogen, growth, mycelia}

\section{Pendahuluan}

Fungi mikoriza arbuskula merupakan salah satu bentuk simbiosis mutualisme yang terjadi antara akar tanaman dengan fungi. Saat ini diketahui hampir $80 \%$ tanaman bersimbiosis dengan fungi mikoriza arbuskula (Humphreys, 2010). Sebaran yang luas dilingkungan menunjukkan pola simbiosis ini merupakan suatu hal yang penting untuk terus diobservasi. Simbiosis terjadi di dalam akar tanaman dengan cara fungi mengolonisasi apoplast dan sel korteks untuk memperoleh karbon yang berasal dari hasil fotosintesis dari tanaman. Perbedaan lokasi dan rizosfer menyebabkan perbedaan keanekaragaman spesies dan populasi FMA.
Assosiasi dapat diklasifikasikan ke salah satu dari beberapa jenis asosiasi yang terbentuk, seperti fungi mikoriza arbuskula, ectomikoriza, ektendomikoriza, ericoid, arbutoid, berdasarkan jenis fungi yang terlibat dan berbagai struktur yang dihasilkan yang diproduksi oleh fungi dan akar tanaman (Smith, 1997). Penelitian mikoriza selama 50 tahun terakhir telah bergerak di sekitar paradigma bahwa FMA memiliki akses untuk memobilisasi ion mineral sederhana dari tanah ke tanaman inang. Sebuah konsep mendapatkan alasan bahwa seleksi alam mungkin lebih memiliki hubungan antara tumbuhan dan tanaman mutualists yang mampu mendukung penyerapan $\mathrm{N}$ dan $\mathrm{P}$ sebagai nutrisi tanaman 
inang. Secara umum pola pergerakan karbon dominan berasal dari tanaman ke fungi. Pola asosiasi ini seringkali menunjukkan kepada sistem pertahanan tanaman, serapan hara, perbaikan struktur tanah dan ketahanan terhadap cekaman kekeringan. Penelitian berikutnya menunjukkan hubungan yang terus menerus antara fungi dan akar tanaman tanpa melihat kehadiran miselia (Gosling, 2006). Penelitian awal tentang fungi mikoriza arbuskula telah digambarkan mulai tahun 1842 (Nägeli, 1842). Kehadiran FMA (Fungi Mikoriza Arbuskula) pada akar tanaman memberikan keuntungan kepada tanaman tersebut dalam penyerapan unsur hara.

Terdapat pemahaman yang terus tumbuh dari pentingnya kehidupan pertanian yang berkesinambungan, termasuk asosiasi tanaman simbiotik. Di antara simbiosis ini, yang paling utama adalah mikoriza, asosiasi simbiotik yang tersebar luas antara fungi dengan akar tanaman. Pembahasan simbiosis FMA sangat menarik dibahas dalam konteks pertanian, (i) karena FMA dominan yang dibentuk oleh sebagian besar tanaman (kecuali misalnya pada tanaman di Brassicaceae); (ii) karena peran FMA yang berpotensi positif dan multifungsi dalam nutrisi tanaman, perlindungan patogen, toleransi stres dan penyediaan struktur tanah (iii) karena banyak praktik pertanian (misalnya, persiapan lahan, pemupukan, tanaman non-inang) cenderung berdampak negatif pada kehadiran FMA. kelimpahan dan keragaman jamur, sehingga berpotensi memengaruhi fungsi; dan (iv) karena FMA dapat dikelola.

\section{Klasifikasi dan Kehadiran FMA}

$\begin{array}{rrr}\text { Fungi mikoriza } & \text { arbuskula termasuk } \\ \text { kedalam zygomicota } & \text { dengan } & \text { famili }\end{array}$ Acaulosporaceace, Gigasporaceae dan Glomaceae. Masing - masing genusnya adalah Acaulospora dan Enthrophospora untuk Acaulosporaceae, Gigaspora dan Scutellospora untuk Gigasporaceae, Glomus dan Sclerocystis untuk Glomaceae (Dalpé, 1993; Schussler, 2001). Namun, tanah pertanian umumnya didominasi oleh kehadiran hanya beberapa jenis FMA yang termasuk dalam ordo Glomerales. FMA terdiri dari fase internal di dalam fase akar dan fase eksternal, atau fase extraradical mycelium (ERM), yang dapat membentuk jaringan luas di dalam tanah. Asosiasi FMA terjadi karena pembentukan struktur fungi intraseluler yang sangat bercabang atau "arbuscules" yang diyakini sebagai tempat pertukaran fosfat antara fungi dan tanaman. Vesikula yang mengandung lipid dan dianggap sebagai struktur penyimpanan karbon juga dapat terbentuk dalam beberapa kasus, meskipun ini akan tergantung pada simbion jamur serta kondisi lingkungan (Smith, 1997). Sebagian besar penelitian tentang FMA tetap menggunakan akar tanaman sebagai media pertumbuhan FMA. Vesikular merupakan struktur fungi yang berasal dari pembengkakan hifa internal, berbentuk bulat telur dengan ukuran 30-50 $\mu \mathrm{m}$ - sampai $80 \mu \mathrm{m}$ $100 \mu \mathrm{m}$, yang berisi banyak senyawa lemak sehingga merupakan organ penyimpanan cadangan makanan dan pada kondisi tertentu dapat berperan sebagai spora atau alat untuk mempertahankan kehidupan fungi. Jika suplai metabolik dari tanaman inang berkurang, maka cadangan makanan itu akan digunakan oleh fungi sehingga vesikular mengalami degenerasi (Brundrett, 2004). Jika dalam keadaan tidak menguntungkan maka akan terbnetuk spora sebagai sel vegetatig. Secara umum spora yang berkecambah mengandung cadangan makanan dalam bentuk lemak netral (TAG) yang berperan mendukung pertumbuhan. Lemak ini merupakan bentuk utama karbon pada spora, hifa dan vesikel FMA, meliputi 45-95 \% pol karbon spora (Pfeffer, 1999) tergantung pada spesies. Triacyglycerides merupakan bagian terbesar dari lemak pada spora

Asosiasi fungi dan tanaman dapat menguntungkan tanaman terutama dengan meningkatkan serapan ion fosfat, karena kemampuan miselia fungi untuk tumbuh di luar zona penipisan fosfat yang dengan cepat berkembang di sekitar akar (Wu, 2013; Hodge, 2015; Maiti, 2017). Sebagai imbalannya, fungi menerima karbon (C) dari tanaman inang. Manfaat lain untuk tanaman yang telah diidentifikasi meliputi: peningkatan resistensi terhadap serangga pemakan daun (Melo, 2010), meningkatkan ketahanan terhadap cekaman kekeringan (Asrianti, 2016)(Pebriansyah, 2012), peningkatakn resistensi dari infeksi patogen tanah (Manila, 2017; Tkacz, 2015), peningkatan kemampuan toleransi terhadap kadar salinitas dan logam berat (Mollavali, 2016; Miransari, 2017), Peningkatan penyerapan macronutrients selain $\mathrm{P}$, termasuk nitrogen $(\mathrm{N})$ potassium $(\mathrm{K})$ dan magnesium (Mg)(Rosenstock, 2016; Dominguez, 2016).

\section{Pola interaksi di rhizosper}

Fungi mikoriza arbuskula diketahui dapat mempengaruhi pola keanekaragaman tumbuhan dalam berbagai ekosistem secara global. Mikroorganisme tanah mempengaruhi perkembangan fungi dan pembentukan simbiosis. Pembentukan simbiosis dapat terjadi maupun tidak terjadi (Cruz, 2014; Ramírez, 2016). Dampak negatif pada FMA termasuk pengurangan perkecambahan spora dan panjang hifa, penurunan kolonisasi akar dan penurunan aktivitas metabolik miselium internal (Muthukumar, 2017). Dampak positif pada 
simbiosis FMA setelah penambahan rhizobacteria (PGPR), termasuk pseudomonas fluorescent dan mikroorganisme berspora. Sebagai contoh, inokulasi ganda dari PGPR dan FMA dalam memberikan pengaruh terhadap pertumbuhan bintil akar kedelai (Pratama, 2017), pertumbuhan tinggi tanaman (Irianto, 2015; Sitepu, 2010).

Pada beberapa penelitian terdahulu dapat disimpulkan bahwa Inokulasi dengan PGPR dapat meningkatkan kolonisasi akar oleh FMA pada awal infeksi, setelah 10-12 minggu tingkat kolonisasi akar terlepas dari kehadiran PGPR. Dengan demikian, kehadiran PGPR dapat juga diartikan untuk meningkatkan tingkat kolonisasi FMA pada akar tanaman. Selain itu, antara bakteri bintil akar dengan FMA juga bekerja secara sinergis pada akar tanaman. Dipercaya bahwa simbiosis FMA dapat mengurangi tekanan $\mathrm{P}$ untuk tanaman yang pada gilirannya memiliki manfaat peningkatan fikasi nitrogenase, yang pada akhirnya memberikan keuntungan untuk pertumbuhan FMA. FMA sangat tergantung pada pengiriman karbon yang merupakan hasil fotosintesis tanaman inangnya. Bakteri dalam pertumbuhannya membutuhkan unsur karbon (C) sebagai sumber energi untuk kegiatan metabolisme dan perbanyakan sel, sedangkan unsur nitrogen (N) dimanfaatkan untuk mensintesis protein atau pembentukan protoplasma (Simamora, 2006). Akan tetapi, bahan organik yang mempunyai kandungan $\mathrm{C}$ terlalu tinggi menyebabkan proses peruraian terlalu lama, sebaliknya jika kandungan karbon rendah sisa nitrogen akan membentuk amonia dengan konsentrasi tinggi yang toksik bagi bakteri walaupun dalam kondisi aman amonia akan dirubah bakteri menjadi nitrit. Akar tanaman dapat berasosiasi dengan berbagai macam fungi di tanah, walaupun tidak spesifik, sehingga pandangan tentang satu fungi satu jenis tanaman adalah kurang tepat.

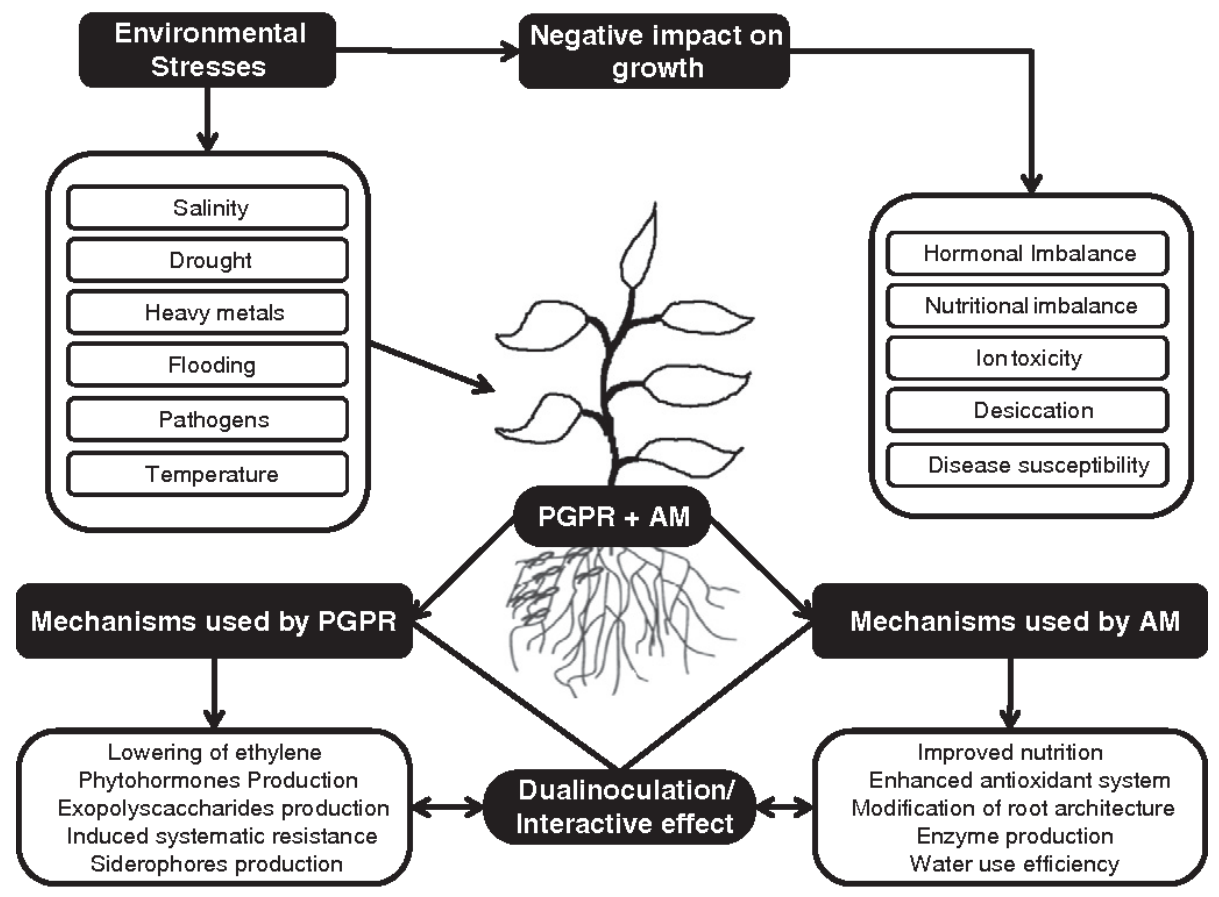

Gambar 1. Interaksi Antara FMA, PGPR dan Akar Tanaman (Sumber : Nadeem, 2014)

\section{FMA Pada Agroekosistem}

Peningkatan penyerapan unsur pospat umumnya dianggap sebagai manfaat penting yang diberikan FMA untuk tanaman inangnya, dan konsentrasi pospat sering menjadi faktor pengontrol utama dalam hubungan tanamanfungi. FMA dapat memainkan peran penting dalam peningkatan jumlah serapan pospat, sehingga tanaman lebih efisien dalam penyerapan pospat (Verzeaux, 2017). Hal ini yang memungkinkan keterkaitan dengan peningkatan pertumbuhan dan hasil tanaman. Ketika kolonisasi oleh FMA terganggu, maka pertumbuhan dapat juga terganggu dalam beberapa kasus. FMA telah banyak digunakan untuk mengurangi efek stres pada tanaman inang dengan meningkatkan ketersediaan nutrisi dan meningkatkan produktivitas pada tanaman inang. 
Meskipun serapan hara telah menjadi fokus banyak penelitian pada asosiasi FMA ada bukti bahwa FMA juga memainkan peran dalam menekan hama dan penyakit tanaman, khususnya penyakit yang dibawa oleh mikroorganisme. Penurunan tingkat penyakit pada tanaman yang telah diinokulasi FMA terjadi, walaupun fakta menunjukkan bahwa infeksi patogen umumnya mengurangi kolonisasi FMA. Dalam beberapa kasus, ketahanan tanaman terhadap hama atau penyakit mungkin hanyalah hasil dari peningkatan nutrisi, meskipun terdapat beberapa penelitian untuk beberapa mekanisme resistensi, mungkin berlangsung secara bersamaan. Mekanisme yang telah diketahui adalah unsur patogen dikeluarkan dari tanaman setelah adanya kolonisasi FMA pada akar tanaman, maka kontrol yang paling efektif adalah, kolonisasi FMA berlangsung terlebih dahulu untuk lebih meningkatkan ketahanan tanaman dari patogen (Al-Hmoud, 2015). Faktor lain yang menyebabkan tingkat ketahanan terhadap patogen tanah adalah perubahan pada eksudat akar yang dapat menyebabkan perubahan pada komunitas mikroba rhizosfer, perubahan pada biokimia akar yang terkait dengan mekanisme pertahanan tanaman. FMA dapat mempengaruhi penyakit yang disebabkan oleh patogen tanah yang mempengaruhi sistem akar. Perubahan pada mekanisme pertahanan tanaman atau resistensi yang diinduksi, dihasilkan dari efek utama dari kolonisasi FMA untuk merespon lebih cepat terhadap infeksi oleh fungi patogen

Secara umum, tanaman mikoriza kurang mengalami kerusakan dan perkembangan patogen akan terhambat. FMA dapat membatasi penyakit akar jamur dengan memperkuat ciri morfologi tanaman dengan beberapa modifikasi fisiologis dan mikroba di rhizosfer dan dengan mengubah komposisi kimia dari jaringan tanaman (Akkpru, 2005). Gangguan dapat mempengaruhi kehadiran FMA di ekosistem pertanian dan alam. Seperti perubahan kondisi kimia, fisika dan biologi tanah. Praktik agronomi seperti penanaman monokultur, pembajakan, atau pemupukan memiliki dampak negatif pada jumlah serta keragaman FMA yang ada di tanah. Pengurangan biomassa fungi akan menghasilkan efek negatif pada stabilitas tanah dan akibatnya dapat meningkatkan risiko erosi tanah. Karena tanah adalah sumber daya tak terbarukan, dampak erosi sering bersifat kumulatif dan dalam banyak hal tidak dapat diubah. Dalam lingkungan yang tercemar oleh senyawa hidrokarbon minyak bumi dan unsur-unsur lainnta, belum didapat bukti yang jelas bahwa FMA langsung dapat mendegradasi senyawa hidrokarbon minyak bumi, namun, mungkin merangsang aktivitas metabolisme mikroorganisme tanah, khususnya bakteri dan fungi, yang menghasilkan percepatan imobilisasi dan translokasi senyawa polutan.

\section{Peningkatan Agregasi Tanah}

Ketertarikan pada FMA cenderung berfokus pada perannya yang langsung mempengaruhi pertumbuhan tanaman inang. Namun, FMA juga memiliki efek langsung pada struktur tanah, yang sangat penting dalam bidang pertanian, di mana budidaya, dan tingkat bahan organik tanah yang rendah cenderung akan menghasilkan struktur tanah yang rusak. Tanaman inang mentranfer sebanyak 20\% karbon ke fungi, dan di laha pertanian, FMA dapat menghasilkan biomassa yang signifikan (Hodge, 2015).

FMA mempunyai kemampunan untuk memantapkan struktur tanah. FMA melalui jaringan hifa eksternal dapat memperbaiki dan memantapkan struktur tanah. Sekresi senyawasenyawa polisakarida, asam organik dan lendir oleh jaringan hifa eksternal yang mampu mengikat butir-butir primer menjadi agregat mikro. Proses ini sangat penting artinya dalam stabilisasi agregat mikro. Kemudian agregat mikro melalui proses "mechanical binding action" oleh hifa eksternal akan membentuk agregat makro yang mantap. Agregasi tanah adalah proses kunci dalam ekosistem yang menghasilkan pembentukan dan stabilisasi struktur tanah, yang terdiri dari agregat tanah dan matriks yang dihasilkan pada pori - pori tanah. Agregasi tanah penting untuk pertumbuhan akar dan untuk fitur tanah dan tingkat proses ekosistem, seperti penyimpanan karbon dan ketahanan terhadap erosi (Coleman, 2017). Agregasi tanah adalah suatu proses yang kompleks, diatur oleh berbagai faktor abiotik (misalnya tekstur) dan dimediasi oleh tanaman dan berbagai kelompok biota termasuk interaksinya, terlepas dari kerumitan ini, akar tanaman dan FMA secara konsisten ditemukan dan menjadi kekuatan penting dalam meningkatkan agregasi tanah. Spesies tanaman dan FMA, masing-masing, berbeda dalam kontribusinya terhadap agregasi tanah (Li, 2015; Leifheit, 2015).

FMA menghasilkan senyawa glycoprotein glomalin yang sangat berkorelasi dengan peningkatan kemantapan agregat tanah. faktorfaktor yang terlibat dalam pembentukan struktur adalah organisme, seperti hifa fungi yang dapat mengikat satu partikel tanah dan partikel lainnya Selain akibat dari perpanjangan dari hifa-hifa eksternal pada FMA, sekresi dari senyawasenyawa polisakarida, asam organik dan lendir yang di produksi oleh hifa-hifa eksternal, mampu mengikat butir-butir mikro tanah menjadi agregat makro. Mekanisme kerja FMA dalam meningkatkan agregart tanah dengan melakukan 
kolonisasi akar tanaman dengan menginfeksi sistem perakaran tanaman inang, memproduksi jalinan hifa secara intensif sehingga tanaman yang mengandung FMA tersebut akan mampu meningkatkan kapasitas dalam penyerapan unsur hara.

\section{Daftar Pustaka}

Akkopru A, Demir S (2005) Biological Control of Fusarium Wilt in Tomato Caused by Fusarium oxysporum f sp lycopersici by AMF Glomus intraradices and some Rhizobacteria. Journal of Phytopathology 153: 544-550

Al-Hmoud, G., \& Al-Momany, A. (2015). Effect of Four Mycorrhizal Products on Fusarium Root Rot on Different Vegetable Crops. Journal of Plant Pathology \& Microbiology, 6(2), 1.

Asrianti, A., Tuheteru, F. D., Kandari, A. M., \& Mekuo, I. S. (2016). Status and Culture of Arbuscular Mycorrhizal Fungi isolated from rhizosphere of Endemic and Endangered Species of Kalapi (Kalappia celebica Kosterm). European Journal of Sustainable Development, 5(4), 395.

Nägeli C (1842). Pilze im Innern von Zellen. Linnaea 16:278-285

Cruz, A. F., Soares, W. R. O., \& Blum, L. E. B. (2014). Impact of the arbuscular mycorrhizal fungi and bacteria on biocontrol of white root rot in fruit seedlings. J Plant Physiol Pathol 2, 1, 2.

Coleman, D. C., Callaham, M. A., \& Crossley Jr, D. A. (2017). Fundamentals of soil ecology. Academic press.

Dalpé, Y. (1993). Vesicular-arbuscular mycorrhiza. Soil sampling and methods of analysis. Lewis Publishers, Boca Raton, 287-301.

Dominguez-Nuñez, J. A., Benito, B., Berrocal-Lobo, M., \& Albanesi, A. (2016). Mycorrhizal fungi: role in the solubilization of potassium. In Potassium solubilizing microorganisms for sustainable agriculture (pp. 77-98). Springer, New Delhi.

Gosling, P., Hodge, A., Goodlass, G., \& Bending, G. D. (2006). Arbuscular mycorrhizal fungi and organic farming. Agriculture, ecosystems \& environment, 113(1-4), 1735.

Hodge, A., \& Storer, K. (2015). Arbuscular mycorrhiza and nitrogen: implications for individual plants through to ecosystems. Plant and soil, 386(1-2), 119.

Humphreys, C. P., Franks, P. J., Rees, M., Bidartondo, M. I., Leake, J. R., \& Beerling,
D. J. (2010). Mutualistic mycorrhiza-like symbiosis in the most ancient group of land plants. Nature communications, 1, 103

Irianto, R. S. (2015). Efektifitas Fungi Mikoriza Arbuskula Dan Plant Growth Promoting Bacteria Terhadap Pertumbuhan Aquillaria Crassna. Jurnal Pemuliaan Tanaman Hutan, 9(3), 149-158.

Leifheit, E. F., Verbruggen, E., \& Rillig, M. C. (2015). Arbuscular mycorrhizal fungi reduce decomposition of woody plant litter while increasing soil aggregation. Soil Biology and Biochemistry, 81, 323328.

Li, X., Zhang, J., Gai, J., Cai, X., Christie, P., \& Li, X. (2015). Contribution of arbuscular mycorrhizal fungi of sedges to soil aggregation along an altitudinal alpine grassland gradient on the Tibetan Plateau. Environmental microbiology, 17(8), 2841-2857.

Maiti, D., Toppo, N. N., Nitin, M., \& Kumar, B. (2017). Arbuscular Mycorrhizal Technology Based on Ecosystem Services Rendered by Native Flora for Improving Phosphorus Nutrition of Upland Rice: Status and Prospect. In Mycorrhiza-EcoPhysiology, Secondary Metabolites, Nanomaterials (pp. 87-105). Springer, Cham.

Manila, R., \& Nelson, R. (2017). Nutrient uptake and promotion of growth by Arbuscular Mycorrhizal Fungi in Tomato and their role in Bio-protection against the tomato wilt pathogen. Journal of Microbiology and Biotechnology Research, 3(4), 42-46.

Melo, C. A. D. (2010). Arbuscular mycorrhizal fungal diversity and composition in pastures of the Azores: assessing the impact of management practices (Doctoral dissertation).

Miransari, M. (2017). Arbuscular Mycorrhizal Fungi and Heavy Metal Tolerance in Plants. In Arbuscular Mycorrhizas and Stress Tolerance of Plants (pp. 147-161). Springer, Singapore.

Mollavali, M., Bolandnazar, S. A., Schwarz, D., Rohn, S., Riehle, P., \& Zaare Nahandi, F. (2016). Flavonol glucoside and antioxidant enzyme biosynthesis affected by mycorrhizal fungi in various cultivars of onion (Allium cepa L.). Journal of agricultural and food chemistry, 64(1), 71-77.

Muthukumar, T., Bagyaraj, D. J., \& Ashwin, R. (2017). Arbuscular Mycorrhizal Fungi: Role in Alleviating Salt Stress in Crop Plants. 
Nadeem, S.M., Ahmad, M., Zahir, Z.A., Javaid, A., \& Ashraf, M. (2014). The role of mycorrhizae and plant growth promoting rhizobacteria (PGPR) in improving crop productivity under stressful environments. Biotechnology advances, 32 2, 429-48.

Pebriansyah, A., Karti, P. D. M. H., \& Permana, A. T. 2012. EFFECT OF DROUGHT STRESS AND ADDITION OF ARBUSCULA MYCORRHIZAL FUNGI (AMF) ON GROWTH AND PRODUCTIVITY OF TROPICAL GRASSES (Chloris gayana, Paspalum dilatatum, and Paspalum notatum). Journal of Tropical Forage Science, 2:1, 41-48

Pratama, R. A. (2017). Pengaruh Pemberian Fungi Mikoriza Arbuskula (FMA) dan PGPR terhadap Bintil Akar Tanaman Kedelai Hitam. Jagros: Jurnal Agroteknologi dan Sains (Journal of Agrotechnology Science), 2(1), 36-41.

Pfeffer, Philip E. , David D. Douds Jr., Guillaume Be'card, and Yair ShacharHill. 1999. Carbon Uptake and the Metabolism and Transport of Lipids in an Arbuscular Mycorrhiza. Plant Physiology. American Society of Plant Physiologists. Vol.120 : 587-598

Ramírez, J. G., Osorno, L., \& Osorio, N. W. (2016). Presence of mycorrhizal fungi and a fluorescent Pseudomonas sp. in the rhizosphere of cacao in two agroecosystems and their effects on cacao seedling growth. Agronomía Colombiana, 34(3), 385-392.

Rosenstock, N. P., Berner, C., Smits, M. M., Krám, P., \& Wallander, H. (2016). The role of phosphorus, magnesium and potassium availability in soil fungal exploration of mineral nutrient sources in Norway spruce forests. New Phytologist, 211(2), 542-553.

Simamora H, Salundik. 2006. Meningkatkan Kualitas Kompos. Jakarta : PT Agro Media Pustaka

Sitepu, I. R., \& Mansur, I. (2010). Utilization of Rhizoplane Bacteria and Arbuscular Fungi Mycorrhizal (AFM) to Improve Growth of Jelutong Seedling (Dyera polyphylla Miq. Steenis. Jurnal Silvikultur Tropika, 1(1).

Schussler, A., Schwarzott, D., Walker, C., 2001. A new fungal phylum, the Glomeromycota: phylogeny and evolution. Mycol. Res. 105, 1413-1421

Smith, S.E. and Read, D.J. (1997) Mycorrhizal Symbiosis. Academic Press, London
Tkacz, A., \& Poole, P. (2015). Role of root microbiota in plant productivity. Journal of experimental botany, 66(8), 21672175.

Verzeaux, J., Hirel, B., Dubois, F., Lea, P. J., \& Tétu, T. (2017). Agricultural practices to improve nitrogen use efficiency through the use of arbuscular mycorrhizae: Basic and agronomic aspects. Plant Science, 264, 48-56.

Wu, F., Wang, W., Ma, Y., Liu, Y., Ma, X., An, L., \& Feng, H. (2013). Prospect of beneficial microorganisms applied in potato cultivation for sustainable agriculture. African Journal of Microbiology Research, 7(20), 2150-2158. 